form of the ring, which, in combination with a slight eccentricity, secured its stability. Maxwell found that the irregularities of a ring possessing a permaneht movement ought to be very sensible, and that the appearance of the rings of Saturn was incompatible with that required by his demonstration. He considered the case of a planet occupying the centre of the ring, whereas Laplace's hypothesis required a slight eccentricity. This question was not, however, treated separately, and M. Callandreau has subjected it to mathematical analysis. First, taking the case of a symmetrical ring when the centre of gravity will be on a symmetrical axis, and then the case required by Laplace, viz. that the centre of gravity is not exactly coincident with the geometrical centre, the author shows that the conditions stated by Laplace are not sufficient to ensure stability.

BRoOKs's COMET (a 1890).--This comet was observed at Paris on March 28 and 30 . It was seen as a round nebulosity, about $4 \mathrm{O}^{\prime \prime}$ or $5 \mathrm{O}^{\prime \prime}$ in diameter, with a very pronounced central condensation, and was about the tenth magnitude.

Bright Lines in Stfillar Spectra.-The Rev. T. E. Espin reports the discovery of bright lines in the spectrum of $\theta_{1}$ as well as in that of $\theta_{2}$ Orionis, and possibly in that of $S$ Corona as well.

\section{ON THE DEFORMATION OF AN ELASTIC} SHELL. ${ }^{1}$

THIS paper treats of the deformation of an elastic shell whore radii of curvature are everywhere great in comparison with the thickness, which is supposed uniform. The subject has been dealt with in a very able manner by $\mathrm{Mr}$. A. E. H. Love in a recent paper (Phil. Trans., I885), but it seemed desirable, on various grounds, that it should be attacked from an independent point of view. The method here followed is that explained in a former communication, "On the Flexure of an Elastic Plate" (December 1889 ). The results, as regards the general theory, are closely analogous with those of $\mathrm{Mr}$. Love, and a comparison of the two investigations gives a physical interpretation to the various groups of terms which enter into his equations. There are some differences of detail, arising from a slight difference in the quantities chosen to express the flexural strains, but they are not practically important.

The great difficulty of the present subject, as contrasted with the theory for a plane plate, is, that we cannot draw an absolute line of demarcation between the deformations in which the cardinal feature is the extension of the middle surface, and those which involve flexure with little or no extension. This appears to arise mainly frum the fact pointed out by $\mathrm{Mr}$. Love, that it is in general impossible to satisfy the boundary conditions by a deformation in which the middle surface is absolutely unextended. But, this being admitted, the question remains in any specific problem, as to the amount and distribution of the extension, and, in particular, whether there are any modes of deformation (or of free vibration) in which, after all, it plays only a subordinate part. Mr. Love answers this question in the negative, in opposition to the views advocated by Lord Rayleigh in two well-known papers. In the present communication Mr. Love's argument is examined, and it is pointed out that cases may occur in which the extensions (though comparable with the flexural strains) may be confined to so small a region of the shell (near the edges) that their contribution to the total energy of deformation is insignificant.

In order to bring the matter to an issue in a definite instance, I have chosen the case of a cylindrical plate (such as a boiler plate) bent by a proper application of force over its straight edges, so that the strained form remains a surface of revolution, the circular edges being free. The analytical work in this case is very simple, and the physical meaning of the various terms which occur is easily recognized. In the interpretation of the result it appears that a good deal turns upon the ratio which the breadth of the plate (in the direction of the generating lines) bears to a mean proportional between the radius and the thick ness. If this ratio is large, the bending forces may be practically replaced by two equal and opposite couples uniformly distributed over the straight edges, and having these edges as axes. The strained form is almost accurately cylindrical; near the circular edges we have extensions of the same order as the flexural strains, but these rapidly die out (at the same time

'Abstract of a Paper read by Prof. Horace Lamb, F.R.S., before the Mathematical Society on January 9. fluctuating in sign) as we press inwards, and the anticipation that their total energy would be small compared with that due to flexure is confirmed. In such a case, then, the approximate methods used by Lord Rayleigh, in which no account is taken of the conditions at a free edge, are fully justified. But if, keeping the radius and the thickness constant, we diminish the breadth of the plate until it is comparable with the mean proportional aforesaid, we get a sort of transition case between a plate and a bar, which cannot be satisfactorily treated except on the basis of the general equations. Finally, when the breadth becomes small in comparison with the mean proportional, the plate behaves like a curved bar, and an approximate treatment is again applicable.

In an appendix I have worked out, from the general equations of elasticity, the uniform flexure of an infinitely long cylindrical plate ; this being, at present, the only case of flexure in which it appears easy to carry out the solution (on these lines) to a full interpretation.

\section{SCIENTIFIC SERIALS.}

Timehri, being the Journal of the Royal Agricultural and Commercial Society of British Guiana (printed at the Argosy Press, Demerara, vol. iii., part ii., new series).--This interesting brochure contains matter of general interest, as well as information which might be expected in an agricultural aud commercial journal. Specialization cannot be pushed to its extreme limits in a colony, and a Society of this nature naturally admits matter into its Journal which are not strictly either agricultural or commercial. Thus the papers on primitive games and on the wild 'flowers of 'Georgetown must be regarded, respectively, as of ethnological and purely botanical interest, but, nevertheless, occupy a great part of the number, especially if we leave out of consideration the repolts of meetings and other official matter connected with the working of the Society. Fruit growing in the Gulf States of America, Caracas as a place of resort, and a short paper on some scale insects inimical to vegetation are the principal topics of a distinctly economic value. The paper entitled the "Letters of Aristodemus and Sincerus" is a review of an old book published in $17.85-88$ in twelve volumes, dealing with the colonies of Demerara and Essequibo, and are therefore of great interest to the present population. In 1785 the colonies had just been given over by the French, who held them on behalf of the Dutch for about three years. No town existed up to that date in Demerara, but during the French occupation a little village had grown up in the neighbourhood of Brandwagt, which they called la nouvelle ville, or Longchamps. The fort on the east bank of the Demerara River (now called Fort William Frederick) was also built at the time, and named Le Dauphin, while another on the opposite side was called $\mathrm{La}$ Raine. From such historical, social, scientific, and economic materials a most interesting although somewhat diffusive number has been produced, showing evidence of mental activity and high culture, pleasant to see far away from the main centres of civilization. The style of the writing, the printing, and the illustrations are all of a high class. How far the London publisher, Mr. E. Stanford, of Cockspur Street, is responsible for the excellent "get up" of the volume we are unable to even conjecture; but we trust we may be permitted to say, without offence, that the number of Timehri before us is highly creditable to the literary talent and tastes of British Guiana.

Quarterly Fournal of Microscopical Sience, February. - On the anatomy of the Madreporia; V., by Dr. G. Herbert Fowler (plate xxviii.). Gives an account of the anatomy of Duncania barbadensis, Galaxea esteri, Heterofsammia multilobata, and Bathyactis symmetrica, and gives a figure of the typical structure of the genus Madrepora. - Contributions to the anatomy of earthworms, with descriptions of some new species, by Frank E. Beddard (plates xxix. and xxx.). This paper gives an account of the structure of three new species of Acanthodrilus, with remarks on other species of the genus. The new species are $A$. antarcticus, $A$. rosa, and $A$. dalei. Further remarks on the reproductive organs of Eudrilus, with special reference to the continuity of ovary and oviduct.-On the certain points in the anatomy of Perichæ1a, with description of Perichata intermedia, n.sp.--On the phagocytes of the alimentary canal, by Armand Ruffer (plate xxxi.). Concludes that the wandering cells of the lymphoir tissues of the alimentary canal have the power of proceeding to the free surfaces of such tissues, and of taking into their interior 
lower micro-organism; and foreign matter (charcoal, \&c.): there are both macro-and micruphages; these are stages, the larger can swallow the smaller and dizest them. -Notes on the hydroid phase of Liminocodium sozerrbyi, by Dr. G. Herbert Fowler (plate xxxii.), records abservations made during May 1883 ; neither medusoid or hydroid appeared in 1889 ; two hydroids and a budding medusoid are figured. - Nute on certain terminal organs resembling touch corpuscles or end bulbs in intramuscular connective tissue of the skate, by Dr. G. C. Purvis (plate xxxiii.). - Note on the transformation of ciliated into stratified squamous epithelium as the result of the application of friction, by Drs. J. B. Haycroft and E. W. Carlier (plate xxxiii.). - On the development of the ear and accessory organs in the common frog, by Francis Villy (plates xxxiv. and xxxv.).-On Thelaceros rhizophore, n.g. et sp., an Actinian from Celebes, by P. C. Mitchell (plate xxxvi.). The Actinian here described was obtained by Dr. IIickson in a mangrove swamp in Celebes, by the side of one of the roots of a Rhizophora; the tentacles have compound hollow protuberances round the margins of the oral surface, with numerous small simple or compound hollow protuberances (rudimentary accessory tentacles) in radial lines on the oral disk. -Notes on the genus Monstrilla, Dana, by Gilbert C. Bourne (plate xxxvii.). Gives details of all the known species of this aberrant genus of Copepods. - On the maturation of the ovum, and the early stages in the development of Allopora, by Dr. Sydney J. Hickson (plate xxxviii.). Gives a general summary of events ; the formation and fate of the trophodisc, the changes of the germinal vesicle, the formation of the embryonic ectoderm the history of the yolk, and general considerations.

\section{SOCIETIES AND ACADEMIES}

\section{LONDON.}

Royal Society, March 27.- "The Variability of the Temwerature of the British Isles, $1859-83$ inclusive." By Robert $H$. icott, F.R.S.

The material discussed has been the daily mean temperature xlerived from twenty-four hourly measurements of the thermosrams at the seven British observatories during the period of iheir continuance, $1869-83$.

The differences between the successive daily means have been extracted, irrespective of sign, and these values averaged monthly.

To the figures for the 7 observatories certain values have been added from Dr. Hann's paper in the Sitzungrberichte of the Vienna Academy for 1875 for Makerstoun and Oxford, the only British stations in Hann's list, and for Vienna, St. l'etersburg, and Barnaul, as instances of Continental climates, as well as for Georgetown, Denerara, as an instance for a tropical station.

The figures for the 7 stations are much lower than those for Makerstoun and Oxford, probably owing to the fact that the means used in the two latter cases were not twenty-four hourly, nor for as many as fifteen years.

The highest variability on the mean of the year is at Kew $\left(2^{\circ} 7\right)$. Then follow Armagh, Glasgow, and Stonyhurst $\left(2^{\circ} \cdot 5\right)$, Aberdeen $\left(2^{\circ} \cdot 4\right)$, and Falmouth and Valencia $\left(1^{\circ} \cdot 9\right)$. The yreatest absolute monthly value is $5^{\circ} .4$ for Glasgow, November 1880 ; the least, $0^{\circ} \cdot 7$, for Valencia, July 1879 .

The mean values for each month are given.

The question of whether great changes are more frequently positive or negative has been investigated. Mr. Blanford states ("Climate of India") that in India (Calcutta and Lahore) sudden falis of temperature are more frequent and greater than sudden rises.

$\Lambda$ preliminary inquiry showed that it was not interesting to investigate all changes, as the numbers showing + and - signs respectively were nearly equal

The changes above $5^{\circ}$ in the twenty-four hours were all examined, and the result showed that in these islands sudden rises of large amount are more frequent and more extensive in amount than sudden falls - the reverse to what obtains in India.

One instance of a rise of $23^{\circ} \cdot 8$ at Aberdeen, Dicember 16,

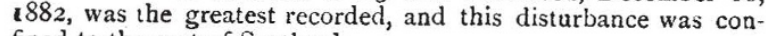
fined to the east of Scotland.

The figures were then examined for frequency. The values were arranged, irrespective of sign, according to their magnitude, in six subdivisions: $-0-0^{\circ} \cdot 9,1^{\circ} 0-4^{\circ} \cdot 9,5^{\circ} 0-9^{\circ} \cdot 9$,
$10 \circ-14^{\circ} 9,15^{\circ} 0-19^{\circ} 9,20^{\circ} 0-24^{\circ} .9$, and the totals divided by 15 . The first two intervals taken together are equal to one of the others, but, as by far the greater number of the changes fell below $5^{\circ} \circ$, it seemed well to see how many fell below $1^{\circ} \circ$.

The range of changes is least at Falmouth and Valencia. In all cases the mean number of changes between $1^{\circ} \circ$ and $4^{\circ} \%$ exceeds half the number of days in the month.

The daily mean values have also all been examined, with the view of discovering their distribution on the thermometer scale.

Seven columns were taken, covering the space from $10^{\circ}$ to $80^{\circ}$, of $10^{\circ}$ each, excepting that the space from $20^{\circ}$ to $40^{\circ}$ was not divided equally.

In I $88 \mathrm{I}$, Stonyhurst had four days in January with a mean below $20^{\circ}$, and nineteen days in which the mean temperature was below $32^{\circ}$. At Aberdeen and Glasgow the cold was not so intense. Neither at Falmouth nor Valencia did the mean temperature ever fa!l below $20^{\circ}$. The hottest station is Kew. In the fifteen years it shows in all thirty-five days with a mean above $70^{\circ}$.

The figures were then divided by 15 , to obtain frequency, as before, and the results shown. They are also shown graphically in a plate, but there all the curves do not appear. Those for Valencia and Falmouth agree almost exactly, except in July and August. Those for Armagh, Glasgow, and Stonyhurst are so close to each other, that one curve is taken to represent all.

Royal Microscopical Society, March 19.--Prof. Urban Pritchard, Vice-President, in the chair.-A letter from the President, regretting his inability to attend in consequence of a fall, was read.--Mr. J. Mayall, Jun., read a letter from Prof. E. Abbe, of Jena, announcing the donation of one of Zeiss's new apochromatic $1^{1} \frac{0}{6}$ objectives of $1 \cdot 6$ N.A. He also sent a condenser of $1 \cdot 6$ N.A., and a flint glass slide containing mixed diatoms mounted by Dr. H. van Heurck, of Antwerp, together with a supply of flint glass slips and cover-glasses for use in mounting objects for examination with the new objective. It was of course understood that in order to exhibit the full power of the increased aperture it was necessary to employ a condenser of corresponding aperture, and the objects to be viewed must be mounted on slips with covers, and mounting and immersion fluids of correspondingly high refractive power. In order to further test this lens, a committee has been appointed. ' Mr. Mayall called attention to and described two microscopes by MM. Nachet and Pellin, of Paris, which were exhibited by Mr. Crisp.-Mr. Rousselet exhibited a number of Rotifers to show their abundance at this season of the year.-A specimen sent by Colonel O'Hara, supposed to be some kind of entozoon which had been passed in urine, was exhibited.-Prof. Bell gave a rísumé of Mr. A. D. Michael's paper on the variations of the female reproductive organs, especially the vestibule, in different species of Uropoda, the author being unavoidably absent through illness.-Mr. C. H. Wright exhibited and described specimens of a new British Hymenolichen, Cy'conema interruptum.-Mr. E. M. Nelson read a short note on the images of external objects produced from the markings of P. formosum. - A note was read from Dr. H. van Heurck correcting an error in his recent communication to the Society relating to the structure of diatoms. - Mr. Mayall read a translation of an article by Prof. E. Abbe on the use of fluorite for optical purposes, in which it appeared that the special qualities of the new apochromatic lenses were due to the employment of this mineral in their construction. Mr. C. H. Gill read a paper on some methods of preparing diatoms so as to exhibit clearly the nature of the workings, which was illustrated by numerous photomicrographs. $-\mathrm{Mr}$. P. Brabam exhibited and described a new form of oxyhydrogen lamp adapted for microscopical purposes, the lamp being so mounted as to be used in any position above or below the object. Its application to photomicrography was demonstrated in the room.-Mr. Clarkson also exhibited one of the same lamps separate from the photomicrographic arrangement. The next conversasione was announced to take place on April 30.

Zoological Society, March 18.-Prof. W. H. Flower, F.R.S., President, in the chair.-The Secretary exhibited (on behalf of the Rev. G. H. R. Fisk) a specimen of a White Bat, obtained at Somerset West, near Cape Town, believed to be an albino variety of Vesperus cafensis. - Captain Percy Armitage exhibited and made remarks on two heads of the Panolia Deer (Corius eliti), obtained on the Sittang River, Burmal. One of 